\title{
ILEUMYCIN, A NEW ANTIBIOTIC AGAINST GLOMERELLA CINGULATA
}

\author{
Yoshiyuki Kawakami, Sumio Matsuwaka, Toshio Otani, \\ Hisao Kondo and SHoshiro NaKamura \\ Institute of Pharmaceutical Sciences, Hiroshima University \\ School of Medicine, Kasumi, Hiroshima, Japan \\ (Received for publication October 11, 1977)
}

\begin{abstract}
A new antifungal antibiotic, named ileumycin, was isolated from culture broth of Streptomyces $\mathrm{H}$ 698-SY2, which was identified as S. lavendulae. The antibiotic was recovered from the culture filtrate by adsorption on Amberlite XAD-II and elution with aqueous methanol and was further purified by ion-exchange column chromatography on SE-cellulose and followed by partition chromatography on silica gel. The antibiotic was named ileumycin, because isoleucine was detected in the acid hydrolyzate of the antibiotic. Ileumycin exhibited antimicrobial activity against only a few species of fungi.
\end{abstract}

In the course of our screening for new antibiotics against plant pathogenic fungi, Streptomyces H 698-SY2 was shown to produce an antifungal antibiotic effective against Glomerella cingulata, a plant pathogenic fungus for grapevines, but not against other fungi, yeasts and bacteria. Sitreptomyces $\mathbf{H}$ 698-SY2 was isolated from a soil sample collected at Kōchi City, Kōchi Prefecture, and classified as belonging to $S$. lavendulae ${ }^{1)}$.

The antifungal activity was determined by the cylinder-agar plate method using Glomerella cingulata as test microbe on potato sucrose agar. The test microbe, grown for 3 days at $27^{\circ} \mathrm{C}$ on a potato sucrose agar slant, was suspended in $2 \mathrm{ml}$ of saline to make a mycelial suspension. The mycelial suspension $(2 \mathrm{ml})$ and potato sucrose agar $(25 \mathrm{ml})$ were combined to make the seed agar. The seed agar $(5 \mathrm{ml})$ was poured over a bottom layer of agar $(10 \mathrm{ml}$ of potato sucrose agar) to make the assay plate. Inhibition diameter of a test sample was measured after incubation at $27^{\circ} \mathrm{C}$ for $18 \sim 24$ hours.

\section{Fermentation}

Streptomyces H 698-SY2 was cultured in shake flasks each containing $100 \mathrm{ml}$ of an inoculation medium composed of $1.0 \%$ soluble starch and $0.2 \%$ yeast extract $(\mathrm{pH} 7.0)$; incubation was at $27^{\circ} \mathrm{C}$ for 24 hours on a reciprocal shaker (amplitude $7 \mathrm{~cm}, 130$ strokes per minute). This inoculum ( $2 \%$ ) was used to inoculate shake flasks each containing $100 \mathrm{ml}$ of a production medium composed of $1.5 \%$ soluble starch, $1.0 \%$ glucose, $2.0 \%$ soyameal, $0.5 \%$ Ebios (dried yeast, distributed by Tanabe Pharmaceutical Co. Ltd.), $0.25 \% \mathrm{NaCl}, 0.3 \% \mathrm{CaCO}_{3}, 0.0008 \% \mathrm{MnCl}_{2} \cdot 4 \mathrm{H}_{2} \mathrm{O}, 0.0007 \% \mathrm{CuSO}_{4} \cdot 5 \mathrm{H}_{2} \mathrm{O}, 0.0002 \%$ $\mathrm{ZnSO}_{4} \cdot 7 \mathrm{H}_{2} \mathrm{O}$ and $0.0001 \% \mathrm{FeSO}_{4} \cdot 7 \mathrm{H}_{2} \mathrm{O}(\mathrm{pH} 7.6$ before sterilization). The culture was grown at $27^{\circ} \mathrm{C}$ for 4 days on the reciprocal shaker.

\section{Extraction and Purification}

The antibiotic was recovered from the broth filtrate by adsorption on Amberlite XAD-II polystyrene resin, and elution with $80 \%$ aqueous $\mathrm{MeOH}$; the eluate was evaporated to a small volume and lyophilized. The antibiotic was extracted with $n-\mathrm{BuOH}$ at $\mathrm{pH} 8$ from an aqueous solution, then 
Chart 1. Extraction and partial purification of ileumycin

Broth filtrate $(37,000 \mathrm{ml}, \mathrm{pH} 7.2)$

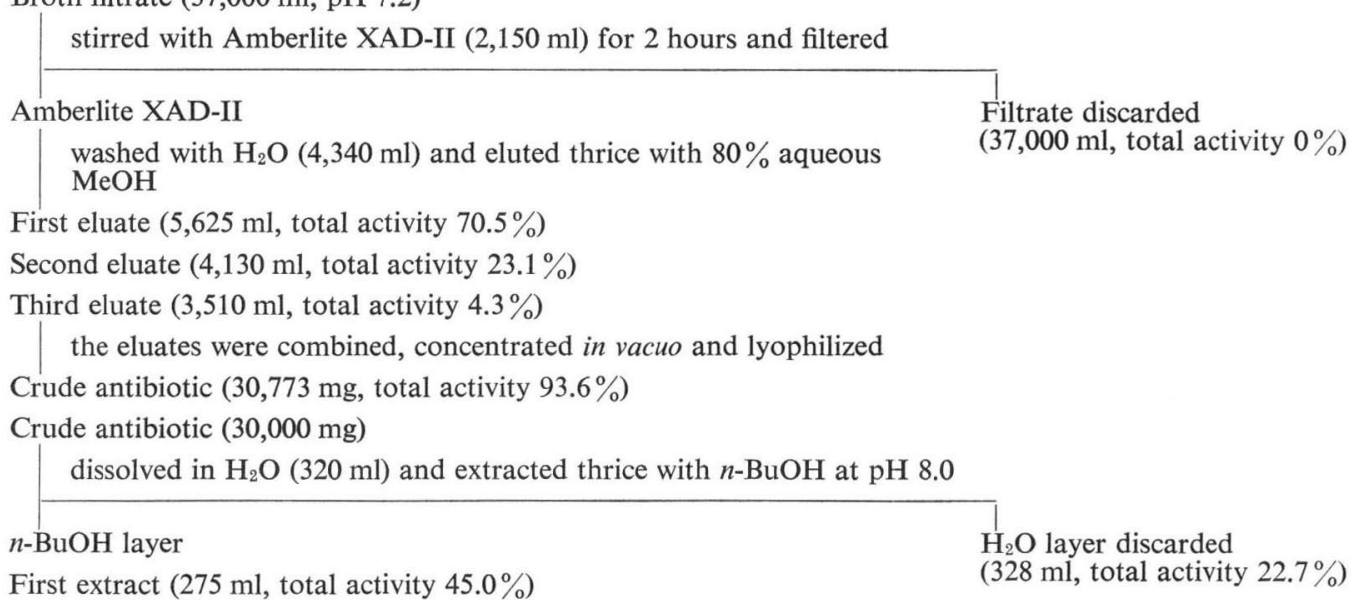

Second extract ( $275 \mathrm{ml}$, total activity $13.6 \%$ )

Third extract $(275 \mathrm{ml}$, total activity $3.3 \%$ )

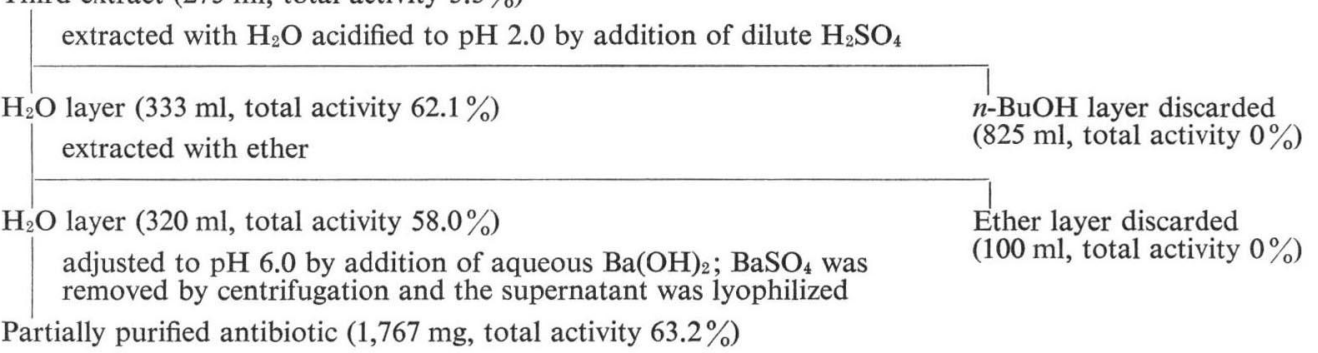

transferred from the $n$ - $\mathrm{BuOH}$ layer to an aqueous layer at $\mathrm{pH} 2$ (Chart 1.). Purification was carried out by ion-exchange column chromatography on SE-cellulose, followed by partition chromatography on silica gel, as summarized in Chart 2. When aqueous sodium chloride is treated with SE-cellulose ( $\mathrm{H}^{+}$-type), $\mathrm{Na}^{+}$is adsorbed on SE-cellulose to liberate $\mathrm{Cl}^{-}$. Thus, the antibiotic on SE-cellulose was recovered as the hydrochloride by elution with a linear gradient concentration of aqueous sodium chloride.

\section{Physical and Chemical Properties}

Ileumycin was obtained as the hydrochloride. It is an amorphous white powder, decomposing at $230 \sim 232^{\circ} \mathrm{C}$. The elemental microanalysis gave $\mathrm{C}, 44.61 ; \mathrm{H}, 6.50 ; \mathrm{N}, 9.74$ and $\mathrm{Cl}, 11.45$. No sulfur was detected.

Ileumycin hydrochloride shows ultraviolet absorption maxima at $220 \mathrm{~nm}\left(\mathrm{E}_{1 \mathrm{~cm}}^{1 \%} 192\right)$ and $280 \mathrm{~nm}$ $\left(\mathrm{E}_{1 \mathrm{~cm}}^{1 \%} 156\right)$ in $\mathrm{H}_{2} \mathrm{O}$; at $222 \mathrm{~nm}\left(\mathrm{E}_{1 \mathrm{~cm}}^{1 \%} 174\right)$ and $278 \mathrm{~nm}\left(\mathrm{E}_{1 \mathrm{~cm}}^{1 \%} 164\right)$ in $0.1 \mathrm{~N} \mathrm{HCl}$; and at $288 \sim 290 \mathrm{~nm}$ $\left(\mathrm{E}_{1 \mathrm{~cm}}^{1 \%} 144\right)$ in $0.1 \mathrm{~N} \mathrm{NaOH}$ as shown in Fig. 1. The infrared absorption spectrum of the antibiotic hydrochloride is shown in Fig. 2. Ileumycin was shown to be homogeneous and appeared as a single spot on silica gel $\mathrm{G}$ thin-layer plates developed with several solvent systems, using bioautography, ninhydrin reaction or heating at $100^{\circ} \mathrm{C}$ for 20 minutes after spraying with $40 \% \mathrm{H}_{2} \mathrm{SO}_{4}$ as detection criteria. The chromatography behavior of the antibiotic on paper strips and silica gel thin-layer plates is described in Tables 1 and 2. The antibiotic gave positive ninhydrin (orange), naphthoresorci- 
Chart 2. Purification of ileumycin

Partially purified antibiotic (777 mg, total activity 100\%)

dissolved in $\mathrm{H}_{2} \mathrm{O}(800 \mathrm{ml})$

SE-Cellulose $\left(\mathrm{H}^{+}\right.$-type, $50 \times 3.2 \mathrm{~cm}$ diam.)

1) washed with $\mathrm{H}_{2} \mathrm{O}(750 \mathrm{ml})$

2) eluted with a linear gradient concentration of $\mathrm{NaCl}$, using $\mathrm{H}_{2} \mathrm{O}$

$(1,500 \mathrm{ml})$ and $0.1 \mathrm{M} \mathrm{NaCl}(1,500 \mathrm{ml}) ; 18-\mathrm{ml}$ fractions were collected

Fractions No. 37 54 (pH 3 4)

lyophilized

Residue (368.1 mg, total activity 91.2\%)

extracted with $\mathrm{MeOH}(8.2 \mathrm{ml})$

$\mathrm{MeOH}$ extract (total activity $63.8 \%$ )

concentrated to $2 \mathrm{ml}$ in vacuo

Residue discarded

(78.0 mg, total activity $0 \%$ )

Sephadex LH-20 column $(50 \times 1.5 \mathrm{~cm}$ diam.)

eluted with $\mathrm{MeOH}$ and collected in 9.4- $\mathrm{ml}$ fractions each

Fractions No. 7 and 8

evaporated to dryness in vacuo

Residue $(64.4 \mathrm{mg}$, total activity $62.8 \%$ )

dissolved in $2 \mathrm{ml}$ of $n$-BuOH - acetone $-\mathrm{H}_{2} \mathrm{O}(4: 1: 1)$

Silica gel column (Merck Kieselgel 60, 70 230 mesh, $58 \times 1.8 \mathrm{~cm}$ diam.)

developed with $n$-BuOH - acetone $-\mathrm{H}_{2} \mathrm{O}(4: 1: 1)$ and collected in $8.8-\mathrm{ml}$ fractions each

Fractions No. $14 \sim 18$

evaporated to dryness in vacuo

Residue ( $28.4 \mathrm{mg}$, total activity $61.5 \%$ )

dissolved in $2 \mathrm{ml}$ of $n$ - $\mathrm{BuOH}$ - acetone $-\mathrm{H}_{2} \mathrm{O}(4: 1: 1)$

Silica gel column (Merck Kieselgel 60, 70 230 mesh, $56 \times 1.8 \mathrm{~cm}$ diam.)

developed with $n$-BuOH - acetone $-\mathrm{H}_{2} \mathrm{O}(4: 1: 1)$ and collected in $10-\mathrm{ml}$ fractions each

Fractions No. $13 \sim 16$

evaporated to dryness in vacuo

Residue (20.9 mg, total activity $60.8 \%$ )

dissolved in abs. $\mathrm{MeOH}(0.5 \mathrm{ml})$, filtered; abs. ether $(8.0 \mathrm{ml})$ was added to the filtrate

Precipitate

dried in vacuo

Supernatant discarded

$(8.5 \mathrm{ml}$, total activity $3.8 \%)$

Purified ileumycin (hydrochloride, $16.3 \mathrm{mg}$, total activity 54.7\%)

Table 1. Paper chromatography behavior of ileumycin (hydrochloride)

\begin{tabular}{l|c}
\hline \multicolumn{1}{c|}{ Solvent systems } & Rf value \\
\hline$n$ - $\mathrm{BuOH}-\mathrm{H}_{2} \mathrm{O}(87: 13)$ & 0.47 \\
$n-\mathrm{BuOH}-\mathrm{H}_{2} \mathrm{O}-\mathrm{AcOEt}(87: 13: 30)$ & 0.46 \\
$n-\mathrm{BuOH}-$ acetone $-\mathrm{H}_{2} \mathrm{O}(8: 2: 1)$ & 0.41 \\
$n$ - $\mathrm{ProOH}-\mathrm{AcOEt}-\mathrm{H}_{2} \mathrm{O}(7: 1: 1)$ & 0.45 \\
sec-BuOH $-\mathrm{H}_{2} \mathrm{O}-\mathrm{AcOEt}(87: 13: 30)$ & 0.31 \\
\hline
\end{tabular}

Table 2. Silica gel $\mathrm{G}$ thin-layer chromatography behavior of ileumycin (hydrochloride)

\begin{tabular}{l|c}
\hline \multicolumn{1}{c|}{ Solvent systems } & Rf value \\
\hline$n-\mathrm{BuOH}-\mathrm{H}_{2} \mathrm{O}(87: 13)$ & 0.14 \\
$n-\mathrm{BuOH}-\mathrm{MeOH}-\mathrm{H}_{2} \mathrm{O}(4: 1: 1)$ & 0.36 \\
$n-\mathrm{ProOH}-\mathrm{AcOEt}-\mathrm{H}_{2} \mathrm{O}(7: 1: 2)$ & 0.68 \\
$n-\mathrm{BuOH}-$ acetone $-\mathrm{H}_{2} \mathrm{O}(4: 1: 1)$ & 0.34 \\
$n-\mathrm{BuOH}-$ acetone $-\mathrm{H}_{2} \mathrm{O}(1: 1: 1)$ & 0.67 \\
\hline
\end{tabular}

nol- $\mathrm{H}_{2} \mathrm{SO}_{4}$ (yellow), Tollens and DragendorfF reactions and decolorized a $1 \% \mathrm{KMnO}_{4}$ solution; The ELSON-MORGAN, $\alpha$-naphthol-phosphate, anthrone-phosphate and SAKAGUCHI reactions were negative. The free base of ileumycin is soluble in $\mathrm{H}_{2} \mathrm{O}$ or $\mathrm{MeOH}$, slightly soluble in EtOH, $n-\mathrm{BuOH}$ 
or dioxane, sparingly soluble in acetone, and insoluble in benzene or $n$-hexane. Ileumycin in an aqueous solution was stable when kept at $100^{\circ} \mathrm{C}$ (pH 2 5) for 5 minutes, but $37 \%$ of the activity (pH 7.0) or $85 \%$ of the activity ( $\mathrm{pH} 8.0$ ) were lost under the same conditions $\left(100^{\circ} \mathrm{C}, 5\right.$ minutes). Ileumycin was hydrolyzed with constant boiling $\mathrm{HCl}$ at $110^{\circ} \mathrm{C}$ for 17 hours and the hydrolyzate gave one ninhydrin-positive spot (Rf 0.78 ), on paper chromatography developed with $n$ - $\mathrm{BuOH}$ $\mathrm{AcOH}-\mathrm{H}_{2} \mathrm{O}$ (4: $\left.1: 1\right)$, which could not be differentiated from those of leucine and isoleucine. The hydrolyzate had the same retention time as isoleucine in the automatic amino acid analyzer.

\section{Biological Properties}

The antimicrobial spectrum of ileumycin is shown in Table 3; the antibiotic shows inhibitory activity only against very few species of plant pathogenic fungi, but not against yeasts and bacteria.
Fig. 1. Ultraviolet absorption spectra of ileumycin (hydrochloride)

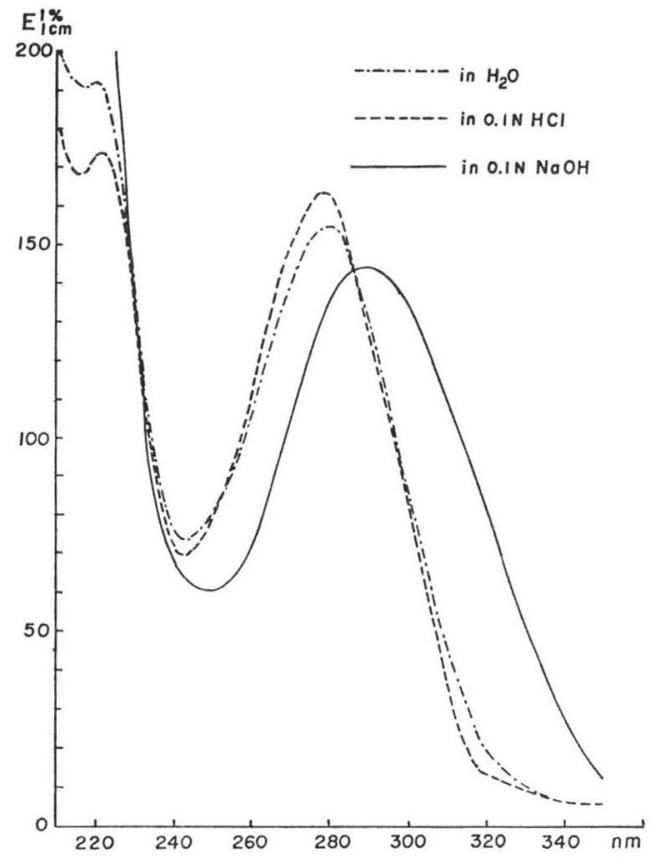

Fig. 2. Infrared absorption spectrum of ileumycin (hydrochloride) in $\mathrm{KBr}$

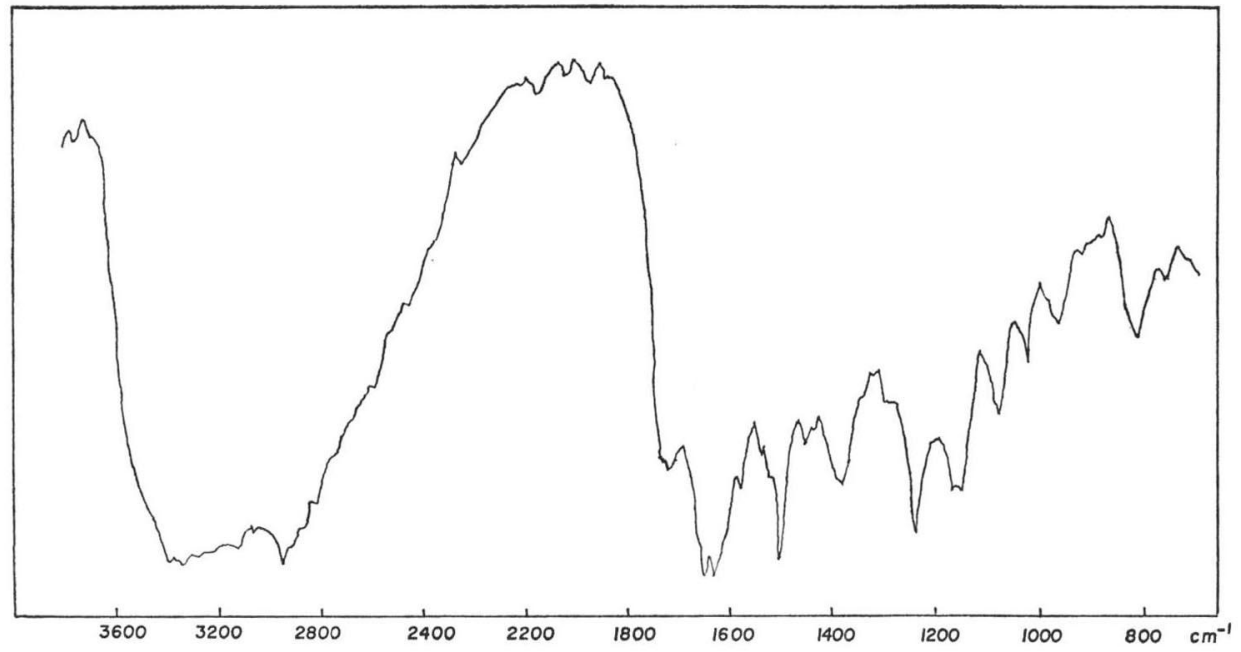

\section{Discussion}

The physico-chemical and biological properties of ileumycin are similar to those of nucleoside antibiotics ${ }^{2}$. Ezomycin $\mathrm{A}_{1}$, a nucleoside antibiotic, is also active against only a few species of plant pathogenic fungi, including Glomerella cingulata, while ezomycin $\mathrm{A}_{2}$ is inactive against Glomerella cingulata $^{3)}$. Nevertheless, ezomycin $\mathrm{A}_{1}$ shows ultraviolet absorption maxima at $278 \mathrm{~nm}\left(\mathrm{E}_{1 \mathrm{~cm}}^{1 \%} 139\right)$ in $0.1 \mathrm{~N} \mathrm{HCl}$, and at $271 \mathrm{~nm}\left(\mathrm{E}_{1 \mathrm{~cm}}^{1 \%} 105\right)$ in $0.1 \mathrm{~N} \mathrm{NaOH}^{3)}$. Ileumycin can be differentiated from ezo- 
Table 3. Antimicrobial spectrum of ileumycin

\begin{tabular}{|c|c|c|c|}
\hline Test organisms & $\begin{array}{c}\text { MIC } \\
(\mathrm{mcg} / \mathrm{ml})\end{array}$ & Test organisms & $\begin{array}{c}\text { MIC } \\
(\mathrm{mcg} / \mathrm{ml})\end{array}$ \\
\hline Staphylococcus aureus FDA 209 P & $>100$ & Candida albicans Yu 1200 & $>100$ \\
\hline Bacillus subtilis PCI 219 & $>100$ & Candida krusei & $>100$ \\
\hline Corynebacterium bovis & $>100$ & Saccharomyces cerevisiae & $>100$ \\
\hline Micrococcus flavus & $>100$ & Colletotrichum lagenarium & 0.78 \\
\hline Micrococcus lysodeikticus IFO 333 & $>100$ & Colletotrichum gloeosporioides Penzig & 0.19 \\
\hline Pseudomonas phaseolicola & $>100$ & Glomerella cingulata & 0.05 \\
\hline Pseudomonas solanacearum & $>100$ & Aspergillus niger $\mathrm{F}-16$ & $>100$ \\
\hline Escherichia coli NIHJ & $>100$ & Alternaria kikuchiana & $>100$ \\
\hline Erwinia carotovora & $>100$ & Gloeosporium laeticolor & $>100$ \\
\hline Agrobacterium tumefaciens & $>100$ & Helminthosporium oryzae & $>100$ \\
\hline Mycobacterium smegmatis ATCC 607 & $>100$ & Trichophyton mentagrophytes (833) & $>100$ \\
\hline Candida tropicalis NI 7495 & $>100$ & Trichophyton asteroides 429 & $>100$ \\
\hline Candida pseudotropicalis NI 7494 & $>100$ & Elsinoë fawcetti BITANCOURT et JENKINS & $>100$ \\
\hline Candida albicans 3147 & $>100$ & & \\
\hline
\end{tabular}

Agar dilution method on potato sucrose agar

mycin $\mathrm{A}_{1}$ by paper chromatography developed with $n$ - $\mathrm{BuOH}-\mathrm{AcOH}-\mathrm{H}_{2} \mathrm{O}(2: 1: 2)$ : $\mathrm{R}$ f value of ezomycin $A_{1}$ is 0.36 , whereas that of the free base of ileumycin is 0.87 .

Ablastmycin $^{4}$, bulgerin ${ }^{5)}$ and SF-1508 ${ }^{6}$ ) have also reported to be active against a limited number of species of plant pathogenic fungi and to show ultraviolet absorption spectra similar to those of ileumycin. Ablastmycin shows ultraviolet absorption maxima at $274 \mathrm{~nm}\left(\mathrm{E}_{1 \mathrm{~cm}}^{1 \%} 270\right)$ in $0.1 \mathrm{~s} \mathrm{HCl}$, and at $235 \mathrm{~nm}\left(\mathrm{E}_{1 \mathrm{~m}}^{1 \%} 225\right)$ and $290 \mathrm{~nm}\left(\mathrm{E}_{1 \mathrm{~cm}}^{1 \%} 185\right)$ in $0.1 \mathrm{~N} \mathrm{NaOH}$. Bulgerin shows maxima at $230 \mathrm{~nm}\left(\mathrm{E}_{1 \mathrm{~cm}}^{1 \%}\right.$ 147, shoulder) and $289 \mathrm{~nm}\left(\mathrm{E}_{1 \mathrm{~m}}^{1 \%} 410\right)$ in $0.05 \mathrm{~N} \mathrm{HCl}$, and $242 \mathrm{~nm}\left(\mathrm{E}_{1 \mathrm{~m}}^{1 \%} 336\right)$ and $306 \mathrm{~nm}\left(\mathrm{E}_{1 \mathrm{~cm}}^{1 \%} 263\right)$ in $0.05 \mathrm{~N} \mathrm{NaOH}$. SF-1508 shows maxima at $295 \mathrm{~nm}\left(\mathrm{E}_{1 \mathrm{~cm}}^{1 \%} 235\right)$ in $0.1 \mathrm{~N} \mathrm{HCl}$, and $243 \mathrm{~nm}\left(\mathrm{E}_{1 \mathrm{~cm}}^{1 \%} 282\right)$ and $312 \mathrm{~nm}\left(\mathrm{E}_{\mathrm{1 \textrm {cm }}}^{1 \%} 180\right)$ in $0.1 \mathrm{~N} \mathrm{NaOH}$.

Thus, ileumycin can be differentiated from the above antibiotics and can be considered to be new.

Acknowledgement

We wish to express our appreciation to Dr. K. SAKATA, Institute of Physical and Chemical Research, for the gift of ezomycins. This work was supported in part by a Grant-in-Aid for Cancer Research No. 201,077 from the Ministry of Education, Japan, to which we are deeply indebted.

\section{References}

1) Shirling, E. B. \& D. Gottlieb: Cooperative description of type cultures of Streptomyces. III. Additional species descriptions from first and second studies. Internat. J. Syst. Bacteriol. 18: 138, 1968

2) Nakamura, S. \& H. Kondo: A brief review of nucleoside antibiotics. Heterocycles (Sendai) 8: 583 607,1977

3) Sakata, K.; A. Sakurai \& S. Tamura: Isolation of novel antifungal antibiotics, ezomycin $\mathrm{A}_{1}, \mathrm{~A}_{2}, \mathrm{~B}_{1}$ and $\mathrm{B}_{2}$. Agr. Biol. Chem. 38: $1883 \sim 1890,1974$

4) Hashimoto, T.; M. Kito, T. Takeuchi, M. Hamada, K. Maeda, Y. OKami \& H. Umezawa: Ablastmycin, a new anti-Piricularia antibiotic. J. Antibiotics 21: 37 43, 1968

5) Shoj, J.; R. Sakazaki, M. Mayama, Y. Kawamura \& Y. Yasuda: A new antibiotic, bulgerin, active against phytopathogenic fungi. J. Antibiotics 23: $295 \sim 299,1970$

6) Shomura, T.; Y. Ogawa, H. Watanabe, J. Yoshida, H. Nakamura, S. Inouye \& T. Niida: Studies on a new antibiotic SF-1508. Sci. Rep. Meiji Seika 15: 9 14, 1976 